IZA DP No. 6399

Interethnic Marriages and their Economic Effects

Delia Furtado

Stephen J. Trejo

February 2012 


\title{
Interethnic Marriages and their Economic Effects
}

\author{
Delia Furtado \\ University of Connecticut \\ and IZA \\ Stephen J. Trejo \\ University of Texas at Austin \\ and IZA \\ Discussion Paper No. 6399 \\ February 2012 \\ IZA \\ P.O. Box 7240 \\ 53072 Bonn \\ Germany \\ Phone: +49-228-3894-0 \\ Fax: +49-228-3894-180 \\ E-mail: iza@iza.org
}

\begin{abstract}
Any opinions expressed here are those of the author(s) and not those of IZA. Research published in this series may include views on policy, but the institute itself takes no institutional policy positions.

The Institute for the Study of Labor (IZA) in Bonn is a local and virtual international research center and a place of communication between science, politics and business. IZA is an independent nonprofit organization supported by Deutsche Post Foundation. The center is associated with the University of Bonn and offers a stimulating research environment through its international network, workshops and conferences, data service, project support, research visits and doctoral program. IZA engages in (i) original and internationally competitive research in all fields of labor economics, (ii) development of policy concepts, and (iii) dissemination of research results and concepts to the interested public.
\end{abstract}

IZA Discussion Papers often represent preliminary work and are circulated to encourage discussion. Citation of such a paper should account for its provisional character. A revised version may be available directly from the author. 
IZA Discussion Paper No. 6399

February 2012

\section{ABSTRACT}

\section{Interethnic Marriages and their Economic Effects ${ }^{*}$}

Immigrants who marry outside of their ethnicity tend to have better economic outcomes than those who marry within ethnicity. It is difficult, however, to interpret this relationship because individuals with stronger preferences for ethnic endogamy are likely to differ in unobserved ways from those with weaker preferences. To clarify some of the complex issues surrounding interethnic marriage and assimilation, this chapter starts by considering the determinants of intermarriage, proceeds with an examination of the economic consequences of intermarriage, and ends with a discussion of the links between intermarriage, ethnic identification, and measurement of long-term socioeconomic integration.

JEL Classification: J12, J15, J61

Keywords: intermarriage, immigration, ethnicity

Corresponding author:

Stephen J. Trejo

Department of Economics

University of Texas at Austin

1 University Station C3100

Austin, TX 78712-0301

USA

E-mail: trejo@austin.utexas.edu

* Forthcoming in: International Handbook on the Economics of Migration. We would like to thank Klaus Zimmermann, Amelie Constant, and two anonymous referees for helpful comments and suggestions. 


\section{INTRODUCTION}

Interethnic marriage rates have often been used as a proxy for the extent of assimilation by immigrant groups (Pagnini and Morgan 1990; Qian and Lichter 2007). Sometimes referred to as "the final stage of assimilation" (Gordon 1964), marriages between immigrants and natives simultaneously measure immigrants' views of the host society and natives' views of the foreign born. Moreover, interethnic marriages can have direct impacts on the participants, including the children produced by these unions. Immigrants that resemble natives are more likely to intermarry, but in sharing a life with a native, immigrants may become even more similar to natives. Closely related to spouse selection and assimilation is ethnic identity, which itself can have important implications for how researchers measure intergenerational integration. ${ }^{1}$

This chapter selectively surveys recent research on these issues by economists and other social scientists. Section 1 discusses the causes of intermarriage, differentiating between determinants related to direct preferences for ethnic endogamy, indirect preferences, and opportunity structures. Section 2 examines the economic consequences of intermarriage, focusing on the empirical methods used to identify causal effects. Section 3 discusses the strong links between intermarriage and ethnic identification and the potential problems that arise for tracking the socioeconomic progress of later-generation descendants of immigrant groups. A final section summarizes and concludes.

\section{DETERMINANTS OF INTERETHNIC MARRIAGE}

In his pioneering work on the economics of marriage, Becker (1973) develops a model of household formation whereby the marriage market generates couples that match on traits which are complements in the production of household goods. Conceptualizing these household goods as companionship, healthy and happy children, and quality of meals, for example, he cites education, religion, and race as examples of traits which are likely to be complements in 
production. In Lam's (1988) model of marriage, the gains from marriage result from the joint consumption, as opposed to production, of household public goods. Since many of the commodities produced within families are also jointly consumed within families, it is optimal for marriages to form between people with similar demands for these goods.

Because ethnic backgrounds of spouses are likely to be complements in the production of ethnicity-related household public goods (such as vacations to the homeland and ethnic meals), both Becker and Lam's models predict marriage market matching based on ethnic background. For similar reasons, spouse-searchers may also find it optimal to match on education, age, language, and religion, for example. In Becker's model, couples are formed in a manner which maximizes aggregate surplus in the marriage market. However, in a world with search costs, optimal matches do not always occur, forcing marriage market participants to make decisions about the characteristics of spouses they value most. Moreover, given the spatial distribution of these traits and the fact that marriage markets tend to be local, ultimate marriage patterns will also depend on who belongs to particular marriage markets.

Thus, the determinants of intermarriage can be classified into three main categories. Starting with the most obvious, some characteristics are suggestive of stronger preferences for ethnic goods consumed within families. Recently arrived immigrants, for example, are likely to value shared ethnicity with a spouse more than people whose families have been in the host country for several generations. The second category relates to preferences for spouse characteristics which are not in themselves about ethnicity, but happen to be more or less common among co-ethnics. For example, high endogamy rates among vegetarian Indians may be driven by tastes for marrying vegetarians, which are relatively more common among Indians, as opposed to tastes for marrying other Indians per se. The final category does not concern preferences at all but is instead related to opportunity. If because of ethnic residential segregation, spouse-searchers are more likely to meet potential spouses with the same ethnic background, then high endogamy rates may result even if marriage market participants are randomly matched with each other. ${ }^{2}$ 
Several researchers have empirically examined the determinants of ethnic intermarriage. ${ }^{3}$ Comparisons between studies are not perfectly straightforward because they use different samples, different definitions of intermarriage, and include different control variables. In fact, while the term "immigrant" most often refers to the foreign born, in some countries, nationality determines immigrant status so that people who were born and raised in a country may be considered foreign if they are not citizens of that country. Even studies relying on US Census data are not directly comparable because questions asked in the Census varied from year to year. For example, Furtado (2012) uses 1970 data on native-born males with two immigrant parents and classifies a marriage as endogamous if a spouse has at least one parent born in the country of birth of the male's father. Chiswick and Houseworth (2011) use 1980 data on immigrants who arrived in the US before marriage and define ethnic endogamy based both on country of birth and ancestry. Furtado and Theodoropoulos' (2011) analysis of 2000 data uses immigrants who arrived in the US before the age of 18 and the native-born who identify with a particular ancestry. The authors classify a marriage as endogamous if both spouses identify with the same ancestry. Despite the different samples and variable definitions, several results appear very robust across studies.

\section{Preferences for Marrying within Ethnicity}

We start by considering those characteristics which are likely to directly impact people's preferences for marrying a co-ethnic. Recently arrived immigrants are more likely to marry endogamously as are immigrants who arrived as older adults (Chiswick and Houseworth 2011). Relative to the foreign born, the native born with two immigrant parents are more likely to marry outside of their ethnicity and the native born with only one foreign-born parent are even more likely to marry out (Kalmijn and van Tubergen 2010). Individuals who identify with multiple ancestries are also likely to marry exogamously (Chiswick and Houseworth 2011). Given that parents tend to prefer endogamous marriages for their children (Kalmijn 1998), people who are 
more tied to the family home are more likely to marry within ethnicity. Not surprisingly therefore, people who marry young are more likely to marry endogamously, while second and higher order marriages are less likely to be endogamous (Chiswick and Houseworth 2011). ${ }^{4}$

There are also certain characteristics which tend to make people more open to marrying outside of their ethnic group. Participation in the military is associated with more exogamous marriages (Furtado and Theodoropoulos 2011; Chiswick and Houseworth 2011), potentially because the military forces soldiers to leave their potentially homogeneous home environments and interact with people from various racial and ethnic groups (Fryer 2007).

Certain features of people's ethnic backgrounds may also make them more accepting of outsiders. Measuring globalization using a combination of several variables--the sum of imports and exports of books, the number of Ikea stores per capita, and the number of McDonalds per capita--Kalmijn and van Tubergen (2010) find that indeed people from more globalized countries are more likely to marry natives. Moreover, even when they marry immigrants or secondgeneration immigrants, their spouses are less likely to share their ethnic background. Males from countries with more ethnic heterogeneity (as measured by Alesina et al. 2003) are also more likely to marry natives than to marry immigrants or second-generation immigrants from the same origin country (Kalmijn and van Tubergen 2010).

\section{Preferences for Other Characteristics}

Turning next to the second category of intermarriage determinants, we consider the role of preferences for characteristics which are not directly related to ethnicity but happen to be correlated with ethnic background. In his seminal paper on the economics of marriage, Becker (1973) cites religion as an example of a trait which is likely to be complementary in the production of household goods. Religious practices in general and especially the religious upbringing of children can be viewed as household public goods, making it optimal, according to Lam's theory, for marriage market participants to match with someone with the same religion. 
Empirically, Lehrer (1998) and more recently Sherkat (2004) find evidence that marrying someone of the same faith is important for spouse-searchers, especially those in certain religions. Another chapter in this volume (the forthcoming International Handbook on the Economics of Migration, edited by Amelie Constants and Klaus F. Zimmerman) specifically considers the religiosity of immigrants.

Given the relationship between religion and ethnic background-Italians tend to be Catholic, Israelis Jewish, and Iranians Muslim - a preference for marrying someone of the same faith may increase the likelihood of marrying a co-ethnic. Empirically examining this hypothesis is difficult because the most often used data sets for studying ethnic intermarriage, at least in the United States, do not contain information on religious background. Noting that the US is predominantly Christian, Kalmijn and Van Tubergen (2010) start by considering the impact of the percentage of a person's home country that is Christian on the probability of marrying within ethnicity. Proxying for a person's religion using the dominant religion in that person's country of origin, they also construct the percentage of respondents in a state who have the same religion after subtracting the number of people from the same country of origin. As might be expected, a Christian background is associated with fewer ethnic intramarriages. In addition, religious similarities to other ethnic groups increase the likelihood of marrying a first or second-generation immigrant from a different country of origin.

Marital preferences need not arise from optimality conditions in models of household production or consumption. Tastes for spouse characteristics may simply reflect social norms. For example, Belot and Fidrmuc (2010) study gender asymmetries in the propensity to outmarry, noting especially that while black males are significantly more likely to marry whites than black females, the opposite is true for Chinese. They present evidence suggesting that preferences for taller husbands than wives, in combination with differences in height distributions across ethnic groups, can explain a significant portion of the gender asymmetries in intermarriage rates. 


\section{Opportunity for Endogamous Marriages}

Regardless of people's preferences for whom to marry, a prerequisite for marriage, at least in modern day society, is that marriage market participants first meet. Independent of preferences, ultimate endogamy patterns will be heavily influenced by the availability of potential partners with the same ethnic background. People from immigrant groups that are not highly represented in the host country will find it more difficult to encounter co-ethnics in the everyday course of their lives. Thus, group size is likely to be an important determinant of intermarriage. In addition, because marriage markets are not national, groups with diffuse settlement patterns are likely to have lower endogamy rates than groups with concentrated settlement patterns.

It is difficult to determine the precise size of spouse-searchers marriage markets. Given tendencies for ethnic groups to self-segregate, defining a marriage market which is too large is likely to underestimate people's opportunities for endogamous marriages. On the other hand, because people with stronger ethnic preferences are more likely to choose to live in ethnic enclaves, defining marriage markets which are too small can confound the roles of ethnic preferences and opportunity. It may not be surprising, therefore, that researchers choose different levels of geography on which to construct availability measures.

Furtado (2012) constructs marriage markets based on county group, the smallest identifiable geographic area publically available from the 1970 US Census Micro Data. Furtado and Theodoropoulos (2011) use metropolitan statistical areas (MSAs) which are larger than the 2000 equivalent of county groups. Presumably even more concerned that using small geographic areas confounds the role of preferences and opportunity, Kalmijn and Van Tubergen (2010) use states. Drawing on information from metropolitan areas and states, Chiswick and Houseworth (2011) construct measures of opportunity using data from the Census year around which people were most likely making marriage decisions. Thus, marriage market variables for 18-27 year olds in 1980 are constructed using 1980 Census data while variables for 46-64 year olds in 1980 are 
constructed using the 1960 Census. Regardless of how they are defined, these studies consistently find that more contact opportunities with co-ethnics are associated with stronger tendencies to marry a co-ethnic.

Sex ratios are another important factor in determining the likelihood of encountering an acceptable same-ethnicity spouse. Chiswick and Houseworth (2011) construct availability ratios as the number of males of appropriate age from the same ethnic group living in a geographic area divided by a corresponding number of females, taking into account the fact that husbands are typically two years older than wives. While they find that sex ratios are important predictors of endogamy, Kalmijn and Van Tubergen (2010) fail to find a similar role for sex ratios defined in a slightly different way. We conclude therefore that the estimated effect of sex ratios on endogamy patterns is not as robust as the estimated effect of group size. This may be because variation in sex ratios is driven by some characteristics of the geographic area, such as labor market opportunities, which affect intermarriage patterns directly.

\section{Characteristics that Affect Endogamy through Multiple Mechanisms}

Some traits do not fit perfectly into only one of the three categories above but instead affect marriage decisions through multiple avenues. Furtado (2012) and Furtado and Theodoropoulos (2011) present evidence suggesting that education affects endogamy decisions through all three mechanisms discussed above. By what they call the cultural adaptability effect, schooling makes people more accepting of cultural differences in spouses resulting in a decreased likelihood of marrying within ethnicity. By the enclave effect, schooling increases the probability of leaving ethnic enclaves, potentially to acquire schooling or because education is associated with more geographically dispersed labor markets (Wozniak 2010). With fewer opportunities for encountering co-ethnics, people with more schooling are less likely to marry endogamously. Finally, the assortative matching effect starts with the premise that people have a preference for marrying someone with a similar level of education, as suggested theoretically in Becker (1973) 
and Lam (1988) and empirically in Schwartz and Mare (2005). Thus, the effect of schooling on ethnic endogamy should depend on the distribution of education by ethnic group. More specifically, education should decrease the probability of marrying within ethnicity for people in low education groups but increase that probability for people in high education groups.

A spouse search model developed in Furtado (2006) demonstrates how these mechanisms operate in a theoretical perspective, while using 1970 US Census data on second-generation immigrants with two foreign-born parents, Furtado (2012) shows that controlling for the enclave effect, there is no empirical support for the cultural adaptability effect but the assortative matching effect seems to be an important mechanism through which schooling affects marriage decisions. Using more recent data on the foreign born who arrived before the age of 18 and natives who identify with a particular ancestry, Furtado and Theodoropoulos (2011) find evidence for all three mechanisms. Measuring assortative matching on education in different ways, Chiswick and Houseworth (2011) as well as Kalmijn and Van Tubergen (2010) also find evidence consistent with both cultural adaptability and assortative matching effects of education.

Host country language acquisition is likely to affect endogamy patterns in similar ways. However, while language proficiency is associated with weaker propensities to marry within ethnicity (Furtado 2012, Furtado and Theodoropoulos 2011), interpretation of this relationship is difficult given that people with stronger ethnic attachments are more likely to marry endogamously and less likely to learn the host country language. Chiswick and Houseworth (2011) address this issue by examining the effect of linguistic distance of the immigrant's mother tongue from English. Although they generally find that people whose native languages are farther linguistically from English are less likely to outmarry, women who speak the languages furthest away from English, Korean and Japanese, are in fact more likely to intermarry, suggesting that something besides language is driving results. Using a potentially more exogenous source of variation in identifying the role of language, Bleakley and Chin (2010) show that English 
proficiency does indeed have a negative causal effect on the probability that immigrants marry someone with the same country of birth. ${ }^{5}$

These studies are not able to disentangle the mechanisms through which host country language acquisition affects endogamy patterns but Kalmijn and van Tubergen (2010) show that an increase in the number of people from other countries that speak the same language increases the likelihood of marrying immigrants or second-generation immigrants from different origin countries relative to marrying natives. This result is certainly suggestive of an assortative matching on language effect.

\section{LABOR MARKET EFFECTS OF INTERETHNIC MARRIAGE}

The previous section showed that there are systematic differences between people who choose to marry within their ethnicity and people who choose to marry-out. Some of these characteristics may indeed be associated with labor market outcomes, but surely marriage outcomes also depend on random encounters and idiosyncratic personality traits. A natural question then is whether, conditional on a person's preferences and characteristics, spouse's ethnicity has any impact on labor market and educational outcomes. Analyzing these effects of intermarriage is interesting in its own right, but more importantly, spouse ethnicity can be viewed as a proxy for whether a person's social circle is comprised mostly of co-ethnics. While the papers discussed in the previous section emphasized the distinction between marrying within ethnicity versus outside of ethnicity, the literature on the economic consequences of intermarriage focus on the distinction between marrying an immigrant and marrying a native. This section examines this literature on the labor market impacts of marriage to a native and by extension, association with natives more generally.

There are several reasons why marriage choice may influence labor market outcomes of immigrants. While it is true that immigrants fluent in the host country's language are more likely to marry outside of their ethnicity (Bleakley and Chin 2010), marrying a native is likely to further 
improve an immigrant's language abilities. A similar story can be told with respect to knowledge of and comfort with the host country's customs and social norms. As immigrants become socially indistinguishable from natives, they are likely to become more successful in the labor market.

Although by definition, marriages involve only two people, in practice, people typically acquire new friends and acquaintances as they start romantic relationships. Given that personal connections play a central role in job acquisitions (Ioannides and Loury 2004), social circle members acquired through marriage may be important in determining the jobs that immigrants get. It is reasonable to assume that new network members are relatively more likely to be nativeborn if an immigrant marries a native and relatively more likely to be an immigrant if he marries another immigrant. Given that natives are more likely to be employed and tend to have higher wages (Larsen 2004), social connections to natives are likely to expose immigrants to better labor market opportunities.

One last mechanism through which marriage may affect wages and employment rates is purely institutional. For undocumented immigrants, marriage to a native may bring with it the legal right to work in the host country. Thus, immigrants who may have been limited to underthe-table work can gain access to a broader range of higher paying more formal jobs.

Within a variety of studies using different samples in different contexts, ordinary least squares (OLS) estimates unambiguously point to a positive labor market impact of marriage to a native. In the seminal paper in this literature, Meng and Gregory (2005) find that intermarried immigrants earn higher wages than endogamously married immigrants even when controlling for observable measures of human capital such as schooling, English proficiency, and years since migration. Similar relationships were found in Denmark (Çelikaksoy 2007), France (Meng and Meurs 2009), the Netherlands (Gevrek 2009), and the US (Kanterevic 2004; Chi 2010) when not controlling for selection into different types of marriages.

It is difficult to interpret these results because the immigrants that marry natives are likely to have different unobservable characteristics than the immigrants that marry other immigrants. If 
the immigrants that marry natives are more assimilated, in ways not captured by the assimilation controls in the models, then ordinary least squares analyses will overstate the labor market returns to marrying natives. On the other hand, if conditional on the measures of assimilation and human capital in the models, the immigrants that marry natives have worse unobservable characteristics, then OLS may actually underestimate the labor market returns to marrying a native.

To address the endogeneity issue, most papers in this literature take an instrumental variables approach, using marriage market conditions to instrument for marriage to a native. Meng and Gregory (2005) use two variables, specifically the number of opposite sex individuals from the person's age-ethnicity-religion group divided by the total number of opposite sex individuals and sex ratios within those age-ethnicity-religion cells, to instrument for intermarriage. They find that IV estimates are larger in magnitude than OLS estimates pointing to negative selection on observables into marrying a native. Meng and Meurs' IV is the number of opposite sex individuals of the same sex, ethnicity and age living in the same region divided by the total number of opposite sex individuals of the same age and living in the same region. Despite using region instead of religion in constructing their IV, Meng and Meurs' (2009) results are similar to those in Meng and Gregory (2005).

In contrast, Kantarevic (2004) finds that after selection is taken into account, immigrants in the US who marry natives do not have higher wages than the immigrants who marry other immigrants. However, also using US data, ${ }^{6}$ Furtado and Theodoropoulos (2010) find that marrying a native increases employment rates of immigrants, especially those with the lowest levels of education. If marriage to a native sufficiently increases employment rates of low-wage immigrants, then selection into the labor force may explain why researchers have failed to find wage effects of marrying a native in the US.

Furtado and Theodoropoulos (2010) go on to explore the mechanisms through which marriage to a native affects immigrant employment. With cross-sectional data, it is not possible to distinguish between language abilities improving after marrying a native or immigrants fluent in 
English being more likely to marry natives. However, they show that adding measures of assimilation, such as English fluency and residence in ethnic enclaves, to the baseline model only decreases the estimated coefficient on marriage to a native by a rather small amount suggesting that there must be other mechanisms through which marrying a native increases the employment probabilities of the foreign born.

To examine whether changes in legal status can explain the employment premium of marriage to a native without information on immigrants' past legal statuses, Furtado and Theodoropoulos (2010) compare the intermarriage returns for immigrants who have characteristics that are most common among undocumented immigrants, such as low levels of education and coming from Mexico and Central America, to those for immigrants without these characteristics. They also compare the returns to marrying a native for Puerto Ricans and Mexicans. These two groups are similar in terms of language, culture, and average education but while a majority of undocumented immigrants in the US are Mexican (Passel and Cohn 2009), Puerto Ricans all have the legal right to work in the US. Furtado and Theodoropoulos also compare the returns from marrying a native to the returns from cohabiting with a native; this comparison is interesting because marriage confers legal status whereas cohabitation does not. These tests suggest that legal status may be part of the explanation for why marriage to a native increases the employment rate of immigrants, but it is unlikely to be the entire explanation. ${ }^{7}$

To explore the role of networks, Furtado and Theodoropoulos (2010) formulate and test a series of hypotheses, based on the network literature, which should hold true if indeed networks can explain why immigrants married to natives are more likely to be employed. For example, they find that the largest returns are for immigrants with the lowest levels of education, that is, those that are most likely to find jobs through networks gained through marriage. They also find the returns are smallest, or even non-existent, for immigrants living in ethnic enclaves. This makes sense in that co-ethnics are more likely to have information about job openings in these ethnic neighborhoods than natives. Consistent with the idea that native contacts are better able to 
aid immigrants in finding wage employment than self-employment, the authors find no evidence that marriage to a native increases the probability of self-employment. In a separate analysis, Georgarakos and Tatsiramos (2009) also find that marriage to a native decreases the probability that immigrants start a business but increases the survival rate of the businesses they do start.

Although the intermarriage literature generally points to a positive impact of intermarriage on labor market success, the validity of all of these results rests on the assumption that the instruments are not correlated with unobserved determinants of wages or employment rates. IV estimates of the returns to marrying a native may overestimate the true relationship if immigrants living in areas with many co-ethnics (or in areas with more males per female) have worse unobservable characteristics or opportunities. Although this is inconsistent with immigrants migrating to areas with better labor market conditions - a typical concern in the immigration literature-it is consistent with the more assimilated and ambitious immigrants leaving their ethnic enclaves.

To address this concern, several new papers have taken a person fixed effects approach using panel data (Nekby 2010 and Nottmeyer 2010). Controlling for all person-specific characteristics which remain stable throughout a person's lifetime, such as unobserved human capital, they examine whether immigrant wages are higher post-marriage when they marry natives as opposed to other immigrants. Using data from Germany, Nottmeyer (2010) finds that, if anything, foreignborn males receive a short term boost in earnings shortly after marrying other immigrants and no statistically significant growth in earnings post-marriage regardless of whether they marry immigrants or natives. Similarly, Nekby’s (2010) analysis of Swedish data points to pre-marriage wage growth for immigrants that eventually marry natives but no wage growth post-marriage. Married immigrant males in her study earn higher wages than single males, but the marriage premium is similar regardless of whether they marry immigrants from the same country of origin, immigrants from a different country of origin, or natives. 
One interpretation of these findings is that the positive estimated labor market returns to intermarriage found in other studies are an artifact of either selection into marrying a native or instrumental variables which do not satisfy the necessary exclusion restrictions. Another interpretation is that the person fixed effects approaches are only able to identify the returns to the change in marital status itself as opposed to association with natives more generally. Given the relatively short panels in both papers, wage comparisons are made just before and just after marriage. Since a great deal of communication between spouses occurs before marriage, it is unlikely that this empirical strategy will pick up many of the returns arising from improvements in host country language fluency or knowledge of social norms. Similarly, because social circles of husband and wife are likely joined before the actual wedding ceremonies, many of the returns arising from social networks will not be identified using this approach.

The panel data approach is able to identify any institutional gains marrying a native. Thus, as long as any required paperwork is processed quickly, the gains to marrying a native as a result of acquiring the legal right to work in a country would be cleanly identified using a panel approach. Under this interpretation, however, it should not be surprising that both Nekby and Nottmeyer find no labor market returns to marrying a native given that Furtado and Theodoropoulos (2010) find only weak evidence that legal status can explain the employment related returns to marrying a native.

Given the difficulties with both the instrumental variables and person fixed effects approaches to identifying the returns to marrying a native, it seems that natural experiments are in order. Unfortunately, it is difficult to find situations generating a change in the likelihood of a particular type of marriage with no impact on labor market opportunities directly. To our knowledge, no such natural experiment has been studied with respect to wages or employment rates, but van Ours and Veenman (2010) exploit one such experiment in their study of educational outcomes of children from interethnic marriages. 
Using exogenous variation resulting from the virtually random allocation of Moluccan immigrants across towns and villages at arrival in the Netherlands, van Ours and Veenman (2010) find that children with a Moluccan father and a Dutch mother have higher educational attainments than children with either two Moluccan parents or a Moluccan mother and Dutch father. The authors conclude that because mothers play a more central role in raising children, it is the origin of the mother that matters for children's educational attainment and familiarity with the Dutch educational system make Dutch mothers especially beneficial.

A remaining question, however, is whether results regarding Moluccan intermarriage in the Netherlands are generalizable. Using 2000 US Census data, Furtado (2009) explores the relationship between marriage to a native and educational outcomes of children from these marriages. Exploiting the fact that parental marriage decisions are made at different times and often different places than 16-17 year old children's high school dropout decisions, Furtado instruments for parental marriage decisions using the size of the foreign born population in the child's birth state in 1980 (just before the children in her sample were born) but controls for the foreign born population in the child's state of residence in the year 2000 (just after dropout decisions are made). She finds that without instrumenting, native-born children with two foreign born parents are more likely to drop out of high school than native-born children with one nativeborn parent. After instrumenting for parental marriage type, however, it is the native-born children with two immigrant parents that are least likely to drop out of high school. In addition, models which control for endogeneity do not yield gender differences in the estimated effect of marriage to a native.

We conclude from this review that marrying a native, and by extension association with natives more generally, is generally associated with more labor market success of immigrants. This result is robust to using data from different countries and constructing the instrumental variables with slightly different functional forms. Positive estimated effects of marriage to a native, however, are not universal. Kantarevic (2004) does not find any evidence that 
intermarriage increases wages for immigrants in the US after controlling for selection into marrying a native. Using person fixed effects approaches, Nekby (2010) and Nottymeyer (2010) also find no evidence of a return to marrying a native in Sweden and Germany respectively. With respect to educational outcomes of children from interethnic marriages, van Ours and Veenman's (2010) results conflict with those in Furtado (2009). In the end, it is difficult to determine whether any conflicting conclusions are a result of the different identification strategies or different contexts. We conclude, therefore, with a call for research which is able to reconcile the conflicting results in the literature.

\section{INTERMARRIAGE AND ETHNICITY}

Sociologists have long recognized the strong links between intermarriage and ethnic attachments. The links are complex and causality runs in both directions. On the one hand, ethnic preferences influence the intensity with which individuals seek out co-ethnics as marriage partners, and ethnic preferences also help determine how readily individuals are accepted as potential mates by those belonging to other groups. As a result, frequent intermarriage is one of the strongest signals of social assimilation by an ethnic group (Gordon 1964; Alba and Nee 2003). On the other hand, interethnic marriage complicates the ethnic origins of the resulting children, which can weaken the ethnic attachments of these children and of those in subsequent generations of the family tree (Alba 1990; Waters; 1990; Perlmann and Waters 2007) After a few generations in the United States, so much intermarriage had taken place among the descendants of European immigrants who arrived in the late 1800s and early 1900s that most white Americans could choose among multiple ancestries or ethnic identities (Alba 1990; Hout and Goldstein 1994; Waters 1990). For such individuals, ethnicity became subjective, situational, and largely symbolic, and the social boundaries between these ethnic groups were almost completely erased. Consequently, intermarriage has been a fundamental source of ethnic flux and leakage in American society (Lieberson and Waters 1988, Hout and Goldstein 1994, Perlmann and Waters 2007). 
In recent years, economists have shown increasing interest in issues related to ethnic identification and intermarriage. An emerging literature within economics explicitly recognizes the complexity of ethnic identification and has begun to investigate the consequences of this complexity for labor market outcomes and policy. In particular, economic models emphasize the potential endogeneity of identity and suggest mechanisms through which ethnic identification could be associated with both observed and unobserved characteristics of individuals and groups. ${ }^{8}$ A related strand of economic research focuses on developing nuanced measures of ethnic identity and the insights gained from analysis of these new measures (Zimmermann 2007; Constant and Zimmermann 2008, 2009). To date, most empirical work in the relevant economics literature has focused on foreign-born immigrants, but some research has begun to analyze the native-born second generation (Constant, Nottmeyer, and Zimmermann 2009; Nekby, Rodin, and Ozcan 2009; Nekby and Rodin 2010).

An important paper by Bisin and Verdier (2000) provides a useful economic framework for thinking about endogenous decisions regarding marriage and the socialization of children and how such decisions influence the evolution of ethnic attachments across generations. A parent hopes that his children will adopt the parent's ethnic or cultural traits. A parent can increase the chances of this happening by marrying a co-ethnic and by exerting greater effort in socializing his children, but the parent faces increasing marginal costs in searching more intensively for a coethnic spouse and also in exerting greater socialization effort. Therefore, members of larger ethnic groups have less incentive to search intensively for a co-ethnic spouse and to exert socialization effort, because being from a larger group improves your chances of finding a coethnic spouse without searching very hard, and being from a larger group also raises the odds that your children are socialized in the preferred way with little effort on your part (because the socializing influence of "society at large" on children is more likely to reflect the ethnic and cultural traits of larger groups). As a result, minority ethnic groups do not vanish across generations through assimilation into the majority, because in equilibrium smaller groups have 
stronger incentives to in-marry and to socialize their children. In this way, minority groups can persist indefinitely, despite intermarriage rates that, when linearly extrapolated from the initial few generations, would suggest a relatively rapid extinction. Instead, endogenous decisions regarding how hard parents work at inculcating ethnic identity among their children produces nonlinear assimilation across generations and the survival of small yet distinct ethnic groups. Bisin, Topa, and Verdier (2004) provide an interesting empirical application of this model to the dynamics of religious populations within the United States.

Duncan and Trejo $(2007,2009,2011,2012)$ argue that selective intermarriage and the resulting "ethnic attrition" can generate potentially serious problems for tracking the socioeconomic progress of later-generation descendants of U.S. immigrant groups. Because of data limitations, research on the U.S.-born descendants of Hispanic and Asian immigrants typically must identify the populations of interest using subjective measures of racial/ethnic identification rather than arguably more objective measures based on the countries of birth of the respondent and his ancestors (Snipp and Hirschman 2004; Duncan, Hotz, and Trejo 2006). In particular, this approach is typically the only feasible option for studies that seek to examine longterm integration by distinguishing immigrant descendants in the third and higher generations (Borjas 1994; Trejo 1997, 2003; Farley and Alba 2002; Smith 2006; Blau and Kahn 2007). A potential problem with this approach is that assimilation and intermarriage can cause ethnic attachments to fade across generations (Alba 1990; Waters; 1990; Perlmann and Waters 2007), and therefore subjective measures of racial/ethnic identification might miss a significant portion of the later-generation descendants of immigrants. Furthermore, if such ethnic attrition is selective on socioeconomic attainment, then it can distort assessments of integration and generational progress.

For the specific case of Mexican Americans, Duncan and Trejo (2007, 2009, 2011) demonstrate the salience of these issues and elucidate the linkages between intermarriage, generational complexity, and ethnic identification. Analyzing microdata from the Current 
Population Survey (CPS) for children living with both parents, Duncan and Trejo (2011) compare an objective indicator of Mexican descent (based on the countries of birth of the child, his parents, and his grandparents) with the standard subjective measure of Mexican identification (based on the response to the Hispanic origin question). Immigrant generations turn out to be quite complex, and this complexity is closely related to children's subjective Mexican identification. For example, only 17 percent of third-generation Mexican children have a majority of their grandparents born in Mexico. Moreover, third-generation children are virtually certain of being identified as Mexican if three or four grandparents were born in Mexico, whereas rates of Mexican identification fall to 79 percent for children with two grandparents born in Mexico and 58 percent for children with just one Mexican-born grandparent. Overall, about 30 percent of third-generation Mexican children are not identified as Mexican by the Hispanic origin question in the CPS, and this ethnic attrition is highly selective. In particular, the high school dropout rate of third-generation Mexican youth (ages 16 and 17) is 25 percent higher when the sample is limited to those youth subjectively identified as Mexican. This research suggests that ethnic attrition is substantial among third-generation Mexicans and could produce significant downward bias in standard measures of attainment which rely on subjective ethnic identification rather than objective indicators of Mexican descent.

Do these findings necessarily mitigate concerns that Mexican Americans are experiencing markedly less intergenerational progress than other U.S. immigrant groups (Huntington 2004; Perlmann 2005)? Duncan and Trejo (2011) show that available data are likely to understate the socioeconomic achievement of later-generation Mexican Americans, but what does this imply about their standing relative to other immigrant groups? Given that intermarriage is the primary source of this bias, we might expect similar or larger biases for other immigrant groups, because most other groups exhibit intermarriage rates at least as high as those of Mexicans (Lieberson and Waters 1988; Lichter and Qian 2005). If the direction of the bias is the same for all groups, then 
appropriate corrections could produce no improvement or even deterioration in the relative position of Mexican Americans.

To address this issue, Duncan and Trejo (2012) investigate selective ethnic attrition for a wide range of national origin groups from important Hispanic (Mexico, Puerto Rico, Cuba, El Salvador, and the Dominican Republic) and Asian (China, India, Japan, Korea, and the Philippines) source countries. Their findings suggest that ethnic attrition generates measurement biases that vary across national origin groups in direction as well as magnitude, and that correcting for these biases is likely to raise the socioeconomic standing of the U.S.-born descendants of most Hispanic immigrants relative to their Asian counterparts. Like Mexicans, Puerto Ricans are an Hispanic group that shows signs of intergenerational stagnation, and the extent and selectivity of ethnic attrition seems roughly similar for U.S.-born Puerto Ricans as for Mexican Americans. The selectivity of ethnic attrition is reversed, however, for Asian-American groups with comparatively high levels of education, such as U.S.-born Chinese, Japanese, Koreans, and Indians. Among the descendants of immigrants from these Asian countries, those with fewer years of schooling are less likely to retain an Asian identification, which suggests that ethnic attrition inflates standard measures of socioeconomic attainment for later-generation Asian Americans. Note that these patterns are broadly consistent with the "assortative matching effect" in Furtado's $(2006,2012)$ model of interethnic marriage, which predicts that members of highattainment groups who intermarry should be negatively selected in terms of attainment, whereas the corresponding selectivity should be positive for intermarried members of low-attainment groups. $^{9}$

\section{CONCLUSION}

Among academics as well as policy analysts, there is a general appreciation for the association between the social integration of immigrants and their economic assimilation. From a theoretical perspective, causality is likely to run in both directions, which makes it difficult to identify 
empirically the underlying mechanisms. Another empirical issue is that, while there are many standard ways to measure economic assimilation, measures of the degree to which immigrants and their children interact with the host society are not as readily available. This chapter selectively surveyed the recent economic literature on one particular measure of immigrants' social integration: interethnic marriage.

We started by considering the determinants of intermarriage, separating them into those factors which are likely to affect preferences for endogamy directly and those which reflect the availability of desirable same-ethnicity potential spouses residing within close geographic proximity. We then turned to an examination of the labor market effects of interethnic marriage. Most studies find beneficial effects for immigrants who marry natives rather than other immigrants, even after accounting for the endogeneity of cross-nativity marriage, but this finding is not universal. In discussing this literature, we offered several ways to interpret seemingly conflicting results. Ultimately, however, further research is needed-ideally, research that explores several different sources of exogenous variation in intermarriage within similar contexts-before we can more definitively determine how and why intermarriage affects economic outcomes.

Finally, we described some of the emerging economic research on the links between intermarriage and ethnic identity. Although this literature is still in its infancy, theoretical work in this area provides important insights into the mechanisms through which ethnicity and culture are transmitted across generations, and related empirical work refines our understanding of ethnic identity and its economic effects and reveals the complexity of immigrant generations. Future work in this area holds much promise.

\section{REFERENCES}

Akerlof, George A. and Rachel E. Kranton (2000), 'Economics and Identity', Quarterly Journal of Economics, 115(3), 715-53. 
Alba, Richard D. (1990), Ethnic Identity: The Transformation of White America. New Haven, CT: Yale University Press.

Alba, Richard D. and Victor Nee, (2003), Rethinking the American Mainstream: Assimilation and Contemporary Immigration. Cambridge, MA: Harvard University Press, 2003.

Alesina, Albertona, Arnaud Devleeschauwer, William Easterly, Sergio Kurlat, and Romain Wacziarg (2003), 'Fractionalization', Journal of Economic Growth, 8(2), 155-94.

Austen-Smith, David, and Roland G. Fryer, Jr., (2005), 'An Economic Analysis of 'Acting White', Quarterly Journal of Economics, 120(2), 551-83.

Becker, Gary S. (1973), 'A Theory of Marriage: Part I', Journal of Political Economy, 81(4), 813-46.

Belot, Michèle and Jan Fidrmuc (2010), 'Anthropometry of love: Height and Gender Asymmetries in Interethnic Marriages', Economics \& Human Biology, 8(3), 361-372.

Bisin, Alberto, Eleonora Patacchini, Thierry Verdier, and Yves Zenou (2011), 'Ethnic Identity and Labour Market Outcomes of Immigrants in Europe', Economic Policy, 26(65), 57-86.

Bisin, Alberto, Giorgio Topa, Thierry Verdier (2004), 'Religious Intermarriage and Socialization in the United States', Journal of Political Economy, 112(3), 615-64.

Bisin, Alberto and Thierry Verdier (2000), 'Beyond the Melting Pot': Cultural Transmission, Marriage, and the Evolution of Ethnic and Religious Traits', Quarterly Journal of Economics, 115(3), 955-88.

Bisin, Alberto and Thierry Verdier (2011), 'The Economics of Cultural Transmission and Socialization', in Jess Benhabib, Alberto Bisin, and Matthew O. Jackson, eds., Handbook of Social Economics, vol. 1A. Amsterdam: North Holland, pp. 339-416.

Bleakley, Hoyt and Aimee Chin (2010), 'Age at Arrival, English Proficiency, and Social Assimilation among U.S. Immigrants', American Economic Journal: Applied Economics, 2(1), 165-92.

Blau, Francine D. and Lawrence M. Kahn (2007), 'Gender and Assimilation among Mexican Americans', in George J. Borjas, ed., Mexican Immigration to the United States. Chicago: University of Chicago Press, pp. 57-106.

Borjas, George J. (1994), 'Long-Run Convergence of Ethnic Skill Differentials: The Children and Grandchildren of the Great Migration', Industrial and Labor Relations Review, 47(4), 553-73.

Çelikaksoy, Aycan (2007), 'A Wage Premium or Penalty: An Analysis of Endogamous Marriage Effects among the Children of Immigrants?', Danish Journal of Economics (Nationalфkonomisk Tidsskrift), 145(3): 288-311.

Chi, Miao (2010), Intermarriage and the Economic Assimilation of Immigrants in the United States. Chapter Doctoral Dissertation, Department of Economics, University of Wisconsin, Milwaukee. 
Chi, Miao and Scott Drewianka (2011), 'How Much is a Green Card Worth? Evidence from Mexican and Puerto Rican Men Who Marry Women Born in the U.S.', available at http://globalnetwork.princeton.edu/publications/fulltext/2.pdf, (accessed 11 January 2012).

Chiswick, Barry and Christina Houseworth (2011), 'Ethnic intermarriage among immigrants: human capital and assortative mating', Review of Economics of the Household, 9(2), 149-80.

Constant, Amelie F., Olga Nottmeyer, Klaus F. Zimmermann (2009), 'Cultural Integration in Germany', IZA Discussion Paper 4675, Institute for the Study of Labor (IZA), forthcoming in: Alberto Bisin, Alan Manning, and Thierry Verdier (eds.), Cultural Integration in Europe, Oxford: Oxford University Press.

Constant, Amelie F. and Klaus F. Zimmermann (2008), 'Measuring Ethnic Identity and Its Impact on Economic Behavior', Journal of the European Economic Association, 6(2-3), 424-33.

Constant, Amelie F. and Klaus F Zimmermann (2009), 'Ethnosizing Immigrants,' Journal of Economic Behavior \& Organization, 69(3), 274-87.

Darity, Jr., William A., Patrick Mason, and James B. Stewart (2006), 'The Economics of Identity: The Origin and Persistence of Racial Norms', Journal of Economic Behavior \& Organization, 60(3), 283-305.

Duncan, Brian, Joseph V. Hotz, and Stephen J. Trejo (2006), 'Hispanics in the U.S. Labor Market', in Marta Tienda and Faith Mitchell, eds., Hispanics and the Future of America. Washington, DC: National Academies Press, pp. 228-90.

Duncan, Brian and Stephen J. Trejo (2007), 'Ethnic Identification, Intermarriage, and Unmeasured Progress by Mexican Americans', in George J. Borjas, ed., Mexican Immigration to the United States. Chicago: University of Chicago Press, pp. 227-69.

Duncan, Brian and Stephen J. Trejo (2009), 'Ancestry versus Ethnicity: The Complexity and Selectivity of Mexican Identification in the United States', Ethnicity and Labor Market Outcomes (Research in Labor Economics, Volume 29), Emerald Group Publishing Limited pp. 31-66.

Duncan, Brian and Stephen J. Trejo (2011), 'Intermarriage and the Intergenerational Transmission of Ethnic Identity and Human Capital for Mexican Americans', Journal of Labor Economics, 29(2), 195-227.

Duncan, Brian and Stephen J. Trejo (2012), 'The Complexity of Immigrant Generations: Implications for Assessing the Socioeconomic Integration of Hispanics and Asians', Manuscript. Austin: University of Texas, January.

Farley, Reynolds and Richard Alba (2002), 'The New Second Generation in the United States', International Migration Review, 36(3), 669-701.

Furtado, Delia (2006), 'Human Capital and Interethnic Marriage Decisions', IZA Discussion Papers 1989, Institute for the Study of Labor (IZA).

Furtado, Delia (2009), 'Cross-Nativity Marriages and Human Capital Levels of Children', in Amelie F. Constant, Konstantinos Tatsiramos, Klaus F. Zimmermann (ed.), Ethnicity and Labor 
Market Outcomes (Research in Labor Economics, Volume 29), Emerald Group Publishing Limited, pp. 273-296.

Furtado, Delia (2012), 'Human Capital and Interethnic Marriage Decisions', Economic Inquiry, 50(1), 82-93.

Furtado, Delia and Nikolaos Theodoropoulos (2010), 'Why Does Intermarriage Increase Immigrant Employment? The Role of Networks', B.E. Journal of Economic Analysis \& Policy, 10(1), Article 101.

Furtado, Delia and Nikolaos Theodoropoulos (2011), 'Interethnic marriage: a choice between ethnic and educational similarities' Journal of Population Economics, 24(4), 1257-79.

Fryer, Roland G. (2007), 'Guess Who's Been Coming to Dinner? Trends in Interracial Marriage over the 20th Century' Journal of Economic Perspectives, 21(2), 71-90.

Georgarakos, Dimitris and Konstantinos Tatsiramos (2009), 'Immigrant self-employment: does intermarriage matter?', in Amelie F. Constant, Konstantinos Tatsiramos, Klaus F. Zimmermann (ed.), Ethnicity and Labor Market Outcomes (Research in Labor Economics, Volume 29), Emerald Group Publishing Limited, pp.253-271.

Gevrek, Z. Eylem (2009), 'Interethnic Marriage and the Labor Market Integration of Immigrants', available at http://www.sole-jole.org/9223.pdf (accessed 11 January 2012).

Gordon, Milton M., (1964), Assimilation in American Life. New York: Oxford University Press.

Hout, Michael and Joshua R. Goldstein (1994), 'How 4.5 Million Irish Immigrants Became 40 Million Irish Americans: Demographic and Subjective Aspects of the Ethnic Composition of White Americans', American Sociological Review, 59(1), 64-82.

Huntington, Samuel P. (2004), Who Are We?: The Challenges to America's Identity. New York: Simon and Schuster.

Ioannides, Yannis M. and Linda Datcher Loury (2004), 'Job Information Networks, Neighborhood Effects, and Inequality’, Journal of Economic Literature, 42(4), 1056-93.

Kalmijn, Matthijs (1998), 'Intermarriage and Homogamy: Causes, Patterns, Trends', Annual Review of Sociology, 24, 395-421.

Kalmijn, Matthijs and Frank van Tubergen (2010), 'A Comparative Perspective on Intermarriage: Explaining Differences in Marriage Choices among National Origin Groups in the United States', Demography, 47(2): 459-479.

Kantarevic, Jasmin (2004), 'Interethnic Marriages and Economic Assimilation of Immigrants', IZA Discussion Papers 1142, Institute for the Study of Labor (IZA).

Lam, David (1988), 'Marriage Markets and Assortative Mating with Household Public Goods: Theoretical Results and Empirical Implications', Journal of Human Resources, 23(4), 462-87.

Larsen, Luke J. (2004), 'The Foreign-Born Population in the United States: 2003', available at http://www.census.gov/prod/2004pubs/p20-551.pdf (accessed 11 January 2012). 
Lehrer, Evelyn L. (1998), 'Religious Intermarriage in the United States: Determinants and Trends', Social Science Research, 27(3), 245-63.

Lichter, Daniel T. and Zhenchao Qian (2005), 'Marriage and Family in a Multiracial Society,' in Reynolds Farley and John Haaga, eds., The American People: Census 2000. New York: Russell Sage Foundation, pp. 169-200.

Lieberson, Stanley and Mary C. Waters (1988), From Many Strands: Ethnic and Racial Groups in Contemporary America. New York: Russell Sage Foundation.

Manning, Alan and Sanchari Roy (2010), 'Culture Clash or Culture Club? National Identity in Britain', Economic Journal, 120(542), 72-100.

Meng, Xin and Robert G. Gregory (2005), 'Intermarriage and the Economic Assimilation of Immigrants', Journal of Labor Economics, 23(1), pages 135-76.

Meng, Xin and Dominique Meurs (2009), 'Intermarriage, Language, and Economic Assimilation Process: A Case Study of France', International Journal of Manpower, 30(1/2), 127-44.

Nekby, Lena (2010), 'Inter- and Intra-Marriage Premiums Revisited: It's Probably Who You Are, Not Who You Marry!', IZA Discussion Papers 5317, Institute for the Study of Labor (IZA).

Nekby, Lena and Magnus Rodin (2010), 'Acculturation Identity and Employment among Second and Middle Generation Immigrants', Journal of Economic Psychology, 31(1), 35-50.

Nekby, Lena, Magnus Rodin, and Bulay Ozcan (2009), 'Acculturation Identity and Higher Education: Is There a Trade-off Between Ethnic Identity and Education?', International Migration Review, 43(4), 938-73.

Nottmeyer, Olga (2010), 'Does Intermarriage Pay Off? A Panel Data Analysis', IZA Discussion Papers 5104, Institute for the Study of Labor (IZA).

Pagnini, Deanna L. and S. Philip Morgan (1990), 'Intermarriage and Social Distance among U.S. Immigrants at the Turn of the Century', American Journal of Sociology, 96(2), 405-32.

Passel, Jeffrey and D'Vera Cohn (2009), 'A Portrait of Unauthorized Immigrants in the United States', Pew Research Center, Washington, DC.

Perlmann, Joel (2005), Italians Then, Mexicans Now: Immigrant Origins and Second-Generation Progress, 1890-2000. New York: Russell Sage Foundation.

Perlmann, Joel and Mary C. Waters (2007), 'Intermarriage and Multiple Identities,' in Mary C. Waters and Reed Udea, eds., The New Americans: A Guide to Immigration since 1965. Cambridge, MA: Harvard University Press, pp. 110-123.

Qian, Zhenchao and Daniel T. Lichter (2007), 'Social Boundaries and Marital Assimilation: Interpreting Trends in Racial and Ethnic Intermarriage', American Sociological Review, 72(1), 68-94. 
Schwartz, Christine R. and Robert D. Mare (2005), 'Trends in Educational Assortative Marriage from 1940 to 2003', Demography, 42(4), 621-46.

Sherkat, Darren E. (2004), 'Religious Intermarriage in the United States: Trends, Patterns, and Predictors', Social Science Research, 33(4), 606-25.

Smith, James P. (2003), 'Assimilation across the Latino Generations', American Economic Review, 93(2), 315-19.

Snipp, C. Matthew and Charles Hirschman (2004), 'Assimilation in American Society: Occupational Achievement and Earnings for Ethnic Minorities in the United States, 1970 to 1990.' Research in Social Stratification and Mobility, 22, 93-117.

Trejo, Stephen J. (1997), 'Why Do Mexican Americans Earn Low Wages?' Journal of Political Economy, 105(6), 1235-68.

Trejo, Stephen J. (2003), 'Intergenerational Progress of Mexican-Origin Workers in the U.S. Labor Market', Journal of Human Resources, 38(3), 467-89.

van Ours, Jan C. and Justus Veenman (2010), 'How Interethnic Marriages Affect the Educational Attainment of Children: Evidence from a Natural Experiment', Labour Economics, 17(1), 111117.

Waters, Mary C. (1990), Ethnic Options: Choosing Identities in America. Berkeley, CA: University of California Press.

Wong, Linda Y. (2003), 'Why so only 5.5\% of Black Men Marry White Women?', International Economic Review, 44(3), 803-26.

Wozniak, Abigail (2010), 'Are College Graduates More Responsive to Distant Labor Market Opportunities?', Journal of Human Resources, 45(4), 944-970.

Zimmermann, Klaus F. (2007), 'Migrant Ethnic Identity: Concept and Policy Implications', Ekonomia, 10(1), 1-17.

\footnotetext{
${ }^{1}$ See the first chapter of this volume (the forthcoming International Handbook on the Economics of Migration, edited by Amelie Constant and Klaus F. Zimmerman) for a discussion of the relationship between assimilation and ethnic identity.

${ }^{2}$ Many researchers have classified the determinants of intermarriage along these lines. In her study of black-white intermarriage, Wong (2003) refers to mating taboos, courting opportunities, and differences in endowments. In Furtado (2012) and Furtado and Theodoropoulos (2011), education affects ethnic endogamy patterns through the cultural adaptability effect, the assortative matching effect, and the enclave effect. Kalmijn and van Tubergen (2010) refer to the first category as a cultural and refer to the second and third categories jointly as structural.

${ }^{3}$ In empirically examining the determinants of intermarriage, researchers must assume, either explicitly or implicitly, that the immigrants in their samples had the opportunity to choose between marrying within ethnicity or outside of ethnicity. We note, however, that some immigrants are only allowed into a host country as a result of whom they marry. To address this issue, researchers typically only consider the marriage decisions of the native born or the foreign born who arrived in a host country before marriageable age.
} 
${ }^{4}$ Although Kalmijn and van Tubergen (2010) do not consider age at marriage directly, they find that early marriage customs in a person's country of origin are associated with increases in the likelihood of endogamy.

${ }^{5}$ They exploit the fact that because of developments in the brain, language acquisition is significantly more difficult after a certain age.

${ }^{6}$ In specifying his IV, Kantarevic (2004) takes the percentage of a person's ethnic group that lives in that person's state and divides that by the percentage of natives that live in the state. Measures are constructed using data on unmarried individuals of the opposite sex. Furtado and Theodoropoulos (2010) use the proportion of people in the person's age group living in that person's MSA that is foreign born as well as the sex ratio in the person's country of origin-age group. While Kantarevic's specifications controlling for selection do not yield statistically significant results, Furtado and Theodoropoulos' (2010) OLS and IV results are not statistically different from each other.

${ }^{7}$ Furtado and Theodoropoulos (2010) demonstrate that Puerto Ricans who marry natives are more likely to be employed than Puerto Ricans who marry immigrants. Chi and Drewianka (2011), however, find that Puerto Ricans receive no wage gain from marrying a native, whereas the corresponding wage gain for Mexicans is 30 percent.

${ }^{8}$ Examples include Akerlof and Kranton (2000); Bisin and Verdier (2000); Bisin, Topa, and Verdier (2004); Austen-Smith and Fryer (2005); Darity, Mason, and Stewart (2006); Manning and Roy (2010); and Bisin, Patacchini, Verdier, and Zenou (2011). Bisin and Verdier (2011) survey some of the relevant literature, as does the chapter on ethnic identity that will appear in the same volume as the current chapter (this volume is the forthcoming International Handbook on the Economics of Migration, edited by Amelie Constant and Klaus F. Zimmerman).

${ }^{9}$ As discussed earlier, Furtado's model emphasizes how the supplies of potential spouses vary with ethnicspecific schooling distributions in marriage markets where individuals hope to match on both education and ethnicity. A college-educated Mexican American, for example, may choose to intermarry because of the relative scarcity of other Mexican ethnics with a college degree. Asian Americans tend to be overrepresented on college campuses, however, so for these groups it may instead be the less-educated individuals that face a more difficult time finding co-ethnics to marry within their education group. Consequently, this model predicts that members of high-education groups who intermarry should be negatively selected in terms of education, whereas the selectivity should be positive for intermarried members of low-education groups. Because intermarriage is a fundamental source of ethnic attrition, the differences across groups in intermarriage selectivity predicted by Furtado's model can generate corresponding differences in the selectivity of ethnic attrition. 